\title{
Jurnal Bestuur
}

\author{
Vol.7, Issue.1, Agustus, 2019 \\ P-ISSN 2302-3783 \\ This work is licensed under a Creative Commons Attribution 4.o International License (cc-by)

\section{Model Pelaksanaan Putusan Mahkamah Konstitusi yang Eksekutabilitas Dalam Pengujian Peraturan Perundang-Undangan di Indonesia}

\author{
I Gusti Ayu Ketut Rachmi Handayani ${ }^{\mathrm{a}}$, Lego Karjoko ${ }^{\mathrm{b}}$ Abdul Kadir Jaelani ${ }^{\mathrm{C}}$ \\ a.b.cFakultas Hukum, Universitas Sebelas Maret, Surakarta - Indonesia. \\ 'Fakultas Hukum, Universitas Slamet Riyadi, Surakarta - Indonesia. \\ Email Coresponden: alanzaelani5o@gmail.com
}

\begin{abstract}
This research is motivated by the number of unimplemented Constitutional Court decisions, although the nature of the Constitutional Court's rulings is final and binding. This form of work is ethical normative. That investigation is descriptive. The data type used is the secondary data. Secondary techniques for the processing of data were obtained through library work. Primary and secondary data were qualitatively analysed. The results of the study show that, first, the decision of the Constitutional Court, which is not implementing the compilation of its decision, does not include a time limit for its implementation, while the decision of the Constitutional Court, which contains a grace period, is quickly followed through the establishment of an invitation regulation. Second, the model of the future functional decision of the Constitutional Court is the decision of the Constitutional Court which contains a period of grace and the institutionalization by constitutional permit of constitutional questions.
\end{abstract}

Keywords: Constitutional Court, time of grace and Issue of the Constitution.

\begin{abstract}
Abstrak
Penelitian ini dilatarbelakangi oleh banyaknya putusan Mahkamah Konstitusi yang tidak implementatif, padahal sifat putusan Mahkamah Konstitusi adalah final and binding. Jenis penelitian yang digunakan adalah penelitian hukum normatif. Penelitian ini bersifat deskriptif. Jenis data yang digunakan adalah data sekunder. Tekhnik pengumpulan data sekunder diperoleh melalui penelitian kepustakaan. Data primer dan sekunder dianalisis secara kualitatif. Hasil penelitian menunjukkan bahwa pertama, putusan Mahkamah Konstitusi yang tidak berwatak implementatif ketika di dalam putusannya tidak mencantumkan tenggang waktu pelaksanaannya, sedangkan putusan Mahkamah Konstitusi yang memuat tenggang waktu ditindak lanjuti sangat cepat oleh pembentuk peraturan perundang-undangan. Kedua, model putusan Mahkamah Konstitusi yang eksekutabilitas ke depan adalah putusan MK yang memuat tenggang waktu dan pelembagaan constitutional question melalui penambahan kewenangan Mahkamah Konstitusi.
\end{abstract}

Keywords: Mahkamah Konstitusi, Tenggang Waktu dan Constitutional Question.

\section{Pendahuluan}

Pengujian Undang-Undang (PUU) adalah tindakan pengujian oleh Mahkamah Konstitusi (MK) untuk menguji konstitusionalitas suatu undangundang, baik secara keseluruhan maupun sebagian. Pengujian konstitusionalitas yang dimaksud menggunakan konstitusi yaitu Undang-Undang Dasar Negara Republik Indonesia Tahun 1945 (UUD NRI 1945) sebagai batu ujinya. UndangUndang dinyatakan konstitusional ketika normanya berkesesuaian dengan norma UUD NRI 1945, dan dinyatakan tidak konstitusional ketika 
sebaliknya.(Luthfi Widagdo Eddyono, 2017) Data Mahkamah Konstitusi menunjukkan bahwa total perkara pengujian peraturan perundang-undangan yang ditangani Mahkamah Konstitusi sejak 2003 hingga September 2019 sebanyak 1.959 perkara dan telah diputus sebanyak 1.258 perkara. (Mahkamah Konstitusi, 2019)

Data tersebut juga menunjukkan bahwa lembaga-lembaga parlemen dan pemerintah terus memproduksi peraturan-peraturan tertulis berupa undangundang sehingga over-regulated, overlapping, disharmoni, multitafsir, konfliktual dan tidak taat asas. Di samping itu, produk hukum yang dilahirkan oleh pembentuk undang-undang, masih cacat ideologis. Dengan kata lain, kualitas produk perundang-undangan sarat akan muatan yang berseberangan dengan konstitusi, tidak partisipatif, aspiratif dan akuntabel.( Bayu Dwi Anggono, 2016)

Dalam kondisi demikian, produk legislasi tidak boleh dibiarkan bertentangan dengan konstitusi. Karena apabila hal ini tetap dibiarkan maka akan terjadi proses deligitimasi konstitusi, pelanggaran hak konstitusional warga negara, bahkan dapat berujung pada ambruknya demokrasi. Itulah sebabnya MK dituntut untuk memainkan perannya melalui kewenangan pengujian undangundang karena diyakini hal itu akan menjadi kekuatanpenyimbang dalam mengontrol produk legislasi yang menabrak konstitusi. Dalam hal ini, kontrol dalam bentuk judicial review dapat menjadi sarana untuk melakukan purifikasi undang-undang yang dihasilkan lembaga legislatif sehingga tidak merugikan masyarakat.( Syukri Asy'ari, Meyrinda Rahmawaty Hilipito dan Mohammad Mahrus Ali, 2013).

Putusan Mahkamah Konstitusi bersifat final, tapi fakta menunjukkan bahwa putusan final MK sering tidak direspon positif oleh lembaga negara lain, putusan final tidak jarang memperoleh tantangan sengit dari segelintir aktor-aktor negara non-yudisial. Meminjam pendapat Hamilto (Fajar Laksono Soeroso, 2013) lembaga yudikatif merupakan cabang yang paling lemah, bahkan untuk dapat mengeksekusi putusannya, peradilan harus dibantu oleh cabang eksekutif dan legislatif, karena eksekutif memiliki pedang (senjata), sedangkan legislatif menentukan atas keuangan negara (dompet). Sebaliknya, cabang yudikatif hanya berwenang memutus perkara.( Alexander Hamilton, 1995) Akibatnya, putusan MK tidak implementatif karena selalu dihadang oleh kompleksitas permasalahan yang mengemuka di tahap aplikasi putusan final, bahkan putusan final MK sering disimpangi oleh lembaga legislatif dalam membentuk peraturan perundangundangan.( Yustina Trihoni Nalesti Dewi, W. Riawan Tjandra, and Grant R. Niemann, 2016)

Problematika tersebut secara epistemologi, menjadi menarik karena putusan Mahkamah Konstitusi bersifat final and binding, namun hanya di atas kertas, tetapi tidak ada jaminan dan mekanisme untuk dilaksanakan. Menurut Fajar Laksono Suroso, (Muchamad Ali Safaat, Aan Eko Widiarto dan Fajar Laksono Suroso, 2017) permasalahan tersebut tergambar jelas dalam UUD NRI 1945 yang menggambarkan bahwa adanya ketimpangan hubungan antara Mahkamah Konstitusi dengan DPR, DPD dan Presiden sebagai pembentuk 
undang-undang. Bahkan UUD NRI 1945 dan UU Mahkamah Konstitusi tidak memuat aturan bagaimana putusan Mahkamah Konstitusi dilaksanakan, kedua peraturan tersebut hanya memuat pernyataan bahwa Mahkamah Konstitusi berwenang mengadili pada tingkat pertama dan terakhir yang putusannya bersifat final dan mempunyai kekuatan hukum sejak selesai diucapkan dalam sidang pleno terbuka untuk umum. Pasal 59 ayat (2) Undang-Undang Nomor 8 Tahun 2011 tentang Mahkamah Konstitusi menyatakan bahwa DPR dan Presiden hanya akan menindaklanjuti putusan Mahkamah Konstitusi jika diperlukan saja. (Amiruddin, 2018) Bahkan putusan final Mahkamah Konstitusi Republik Indonesia akan menemukan jalan panjang, ketika dalam amarnya tidak memuat tenggang waktu pelaksanaan putusan oleh pembentuk peraturan perundangundangan.( Fajar Laksono, Sudarsono, Arief Hidayat and Muchammad Ali Safaat, 2018)

Tindakan tersebut terlihat jelas dalam beberapa putusan diantaranya, pertama, Putusan Mahkamah Konstitusi Nomor 36/PUU-X/2012 tentang Pengujian Undang-Undang Nomor 22 Tahun 2001 tentang Minyak dan Gas Bumi. Kedua, Putusan Mahkamah Konstitusi Nomor 28/PUU-XI/2013 tentang Pengujian Undang-Undang Nomor 17 Tahun 2012 tentang Perkoperasian. Ketiga, Putusan Mahkamah Konstitusi Nomor 85/PUU-XI/2013 tentang Pengujian UndangUndang Nomor 7 Tahun 2004 tentang Sumber Daya Air. Putusan tersebut membatalkan ketentuan dalam peraturan perundang-undangan yang menjadi obyek pengujian, namun tidak memuat tenggang waktu pelaksanaan putusan oleh pembentuk peraturan perundang-undangan. Akibatnya putusan tersebut menegasikan makna Pasal 24C Ayat (1) UUD Tahun 1945 yang menyatakan bahwa Mahkamah Konstitusi berwenang mengadili pada tingkat pertama dan terakhir yang putusannya bersifat final untuk menguji undang-undang terhadap Undang-Undang Dasar. Di satu sisi, tindak lanjut putusan tersebut membutuhkan tindakan dari pembentuk peraturan perundang-undangan melalui proses legislasi (non-self executing).( Pan Mohamad Faiz, 2016)

Tindakan berbeda diperlihatkan oleh pembentuk peraturan perundangundangan menyikapi putusan Mahkamah Konstitusi yang memuat tenggang waktu pelaksanaan putusan oleh pembentuk peraturan perundang-undangan. Misalnya pertama, Putusan Mahkamah Konstitusi Nomor Nomor 32/PUUXI/2013 tentang Pengujian Undang-Undang Nomor 2 Tahun 1992 tentang Usaha Perasuransian. Kedua, Putusan Mahkamah Konstitusi Nomor 22/PUU-XV/2017 tentang pengujian Undang-Undang Nomor 1 Tahun 1974 terhadap UUD NRI 1945. Putusan pertama menegaskan kepada pembentuk undang-undang untuk menindak lanjuti putusan tersebut paling lambat dua tahun enam bulan setelah putusan Mahkamah ini diucapkan. Putusan kedua memerintahkan kepada pembentuk undang-undang untuk menindak lanjuti putusan tersebut paling lambat 3 (tiga) tahun setelah putusan Mahkamah ini diucapkan. Model putusan ini non-self executing, artinya putusan ini tidak dapat dilaksanakan secara langsung tapi Mahkamah Konstitusi secara tegas memberikan batas waktu kepada pembentuk peraturan perundang-undangan untuk menjalankan putusan tersebut. Tulisan ini akan membahas tentang eksekutabilitas putusan Mahkamah 
Konstitusi yang memuat tenggang waktu dalam pembentukan peraturan perundang-undangan serta solusi yang ditawarkan ke depan untuk mengatasi masalah tersebut.

\section{Metode Penelitian}

Jenis penelitian yang digunakan dalam menyusun penelitian ini adalah penelitian hukum normatif yang dilengkapi dengan wawancara. Dengan demikian yang diteliti pada awalnya adalah data sekunder, kemudian dilanjutkan dengan wawancara. Penelitian hukum normatif lebih mengutamakan studi pustaka yaitu kegiatan pengumpulan data yang berasal dari berbagai literatur baik dari perpustakaan maupun tempat lain.(Hermawan Wasito, 1997) Penelitian hukum normatif ini memfokuskan pada asas-asas hukum, sistematika hukum, sinkronisasi hukum, sejarah hukum dalam pembentukan Mahkamah Konstitusi dan lembaga negara di Indonesia.( Soerjono Soekanto, 2018) Penelitian ini menggunakan data sekunder. Alat pengumpulan data sekunder berupa bukubuku yang berkaitan dengan teori dan konsep obyek penelitian, artikel-artikel terkait, literatur karya tulis ilmiah dan lain sebagainya melalui studi pustaka(Maria SW. Sumardjono, 2014) Analisis data yang digunakan dalam penelitian ini adalah analisis kualitatif yang kemudian disajikan dalam bentuk deskriptif. Analisis kualitatif dilakukan melalui kategorisasi berdasarkan permasalahan yang diteliti dan data yang dikumpulkan.(Suharsimi Arikunto, 2018)

\section{Hasil dan Pembahasan}

1. Tindak Lanjut Putusan Mahkamah Konstitusi yang Tidak Memuat Tenggang Waktu dalam Pembentukan Peraturan Perundang-Undangan Tabel 1

Tindak Lanjut Putusan MK yang Tidak Memuat Tenggang Waktu

\begin{tabular}{|c|c|c|c|c|}
\hline \multirow[t]{2}{*}{ PUTUSAN } & \multirow[t]{2}{*}{ Model } & \multicolumn{3}{|c|}{ Bentuk Tindak Lanjut } \\
\hline & & UU & $\begin{array}{c}\text { Peraturan } \\
\text { Pemerintah(Perpres) } \\
\text { /Peraturan Presiden } \\
\text { (PP) }\end{array}$ & Peraturan Menteri \\
\hline $\begin{array}{lr}\text { Putusan MK No. } \\
\text { 36/PUU-X/2012 } \\
\text { tentang Undang- } \\
\text { Undang Nomor } 22 \\
\text { Tahun } \\
\text { tentang } 2001 \\
\text { Minyak }\end{array}$ & $\begin{array}{l}\text { Non Self } \\
\text { Executing }\end{array}$ & - & $\begin{array}{l}\text { Perpres Nomor } 95 \text { Tahun } \\
2012 \text { tentang Pengalihan } \\
\text { Pelaksanaan Tugas Dan } \\
\text { Fungsi Kegiatan Usaha } \\
\text { Hulu Minyak Dan Gas } \\
\text { Bumi }\end{array}$ & $\begin{array}{l}\text { Permen } \text { Energi dan } \\
\text { Sumber Daya Mineral } \\
\text { Nomor } 17 \text { Tahun } 2017 \\
\text { tentang Organisasi dan } \\
\text { Tata Kerja Khusus } \\
\text { Pelaksana } \\
\text { Usaha Hulu Minyak }\end{array}$ \\
\hline
\end{tabular}




\begin{tabular}{|c|c|c|c|c|}
\hline \multirow[t]{2}{*}{ dan Gas Bumi. } & & & & dan Gas Bumi. \\
\hline & & & 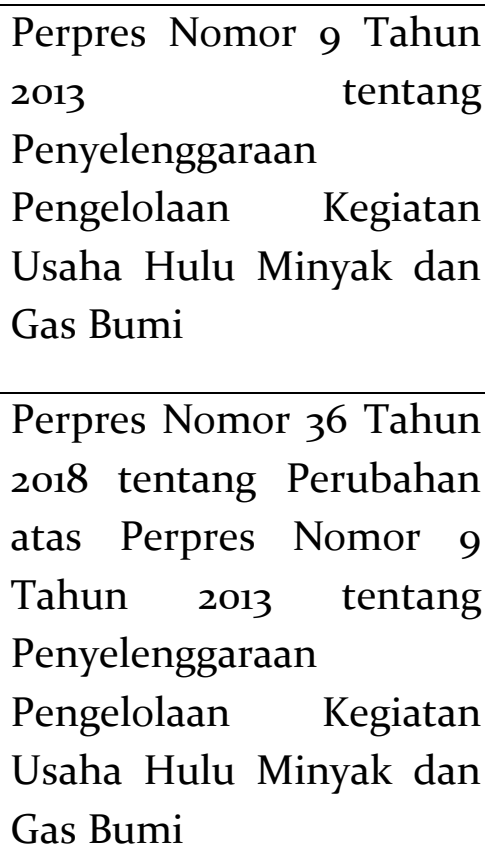 & 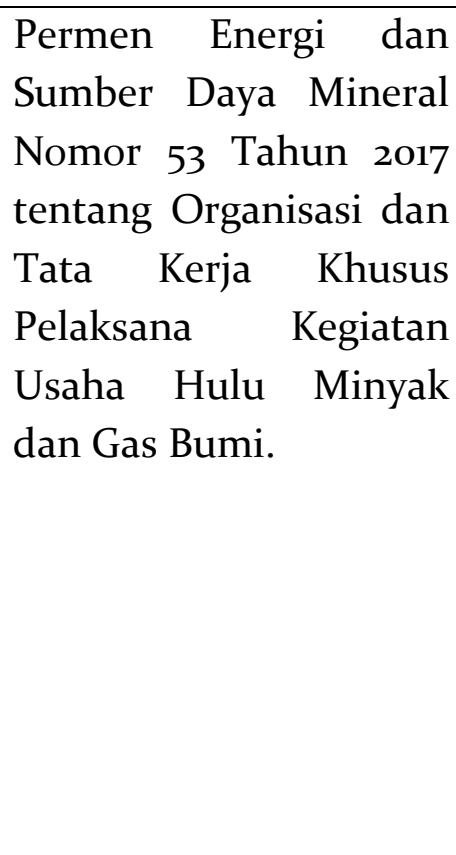 \\
\hline \multirow[t]{3}{*}{$\begin{array}{l}\text { Putusan MK No. } \\
\text { 28/PUU-XI/2013 } \\
\text { tentang Pengujian } \\
\text { Undang-Undang } \\
\text { Nomor 17 Tahun } \\
2012 \text { tentang } \\
\text { Perkoperasian. }\end{array}$} & \multirow[t]{3}{*}{$\begin{array}{c}\text { Non Self } \\
\text { Executing }\end{array}$} & \multirow[t]{3}{*}{-} & \multirow[t]{3}{*}{-} & $\begin{array}{l}\text { Peraturan } \\
\text { Koperasi dan Usaha } \\
\text { Kecil dan Menengah } \\
\text { Nomor } \\
\text { 10/Per/M.KUKM/IX/ } \\
2015 \text { tentang } \\
\text { Kelembagaan Koperasi. }\end{array}$ \\
\hline & & & & $\begin{array}{l}\text { Peraturan } \\
\text { Koperasi dan Usaha } \\
\text { Kecil dan Menengah } \\
\text { Nomor } \\
\text { 11/Per/M.KUKM/IX/ } \\
\text { 2015 tentang Petunjuk } \\
\text { Pelaksanaan } \\
\text { Pemupukan } \\
\text { Penyertaan } \\
\text { Koperasi }\end{array}$ \\
\hline & & & & $\begin{array}{l}\text { Peraturan } \\
\text { Koperasi dan Usaha } \\
\text { Kecil dan Menengah } \\
\text { Nomor }\end{array}$ \\
\hline
\end{tabular}




\begin{tabular}{|c|c|c|c|c|}
\hline & & & & $\begin{array}{l}\text { 15/Per/M.KUKM/IX/ } \\
2015 \text { tentang Usaha } \\
\text { Simpan Pinjam oleh } \\
\text { Koperasi }\end{array}$ \\
\hline \multirow[t]{2}{*}{$\begin{array}{l}\text { Putusan MK No. } \\
\text { 85/PUU-XI/2013 } \\
\text { tentang Pengujian } \\
\text { Undang-Undang } \\
\text { Nomor } 7 \text { Tahun } \\
\text { 2004 tentang } \\
\text { Sumber Daya Air }\end{array}$} & \multirow[t]{2}{*}{$\begin{array}{l}\text { Non Self } \\
\text { Executing }\end{array}$} & \multirow[t]{2}{*}{-} & $\begin{array}{l}\text { PP No. } 121 \text { Tahun } 2015 \\
\text { tentang } \\
\text { Sumber Daya Air }\end{array}$ & $\begin{array}{l}\text { Peraturan Menteri } \\
\text { Pekerjaan Umum Dan } \\
\text { Perumahan Rakyat } \\
\text { Nomor o9/PRT/M/2015 } \\
\text { tentang Penggunaan } \\
\text { Sumber Daya Air. }\end{array}$ \\
\hline & & & \begin{tabular}{lrr} 
PP No. 122 & Tahun 2015 \\
tentang & \multicolumn{2}{c}{ Pengelolaan } \\
Sistem & Penyediaan Air \\
Minum & &
\end{tabular} & 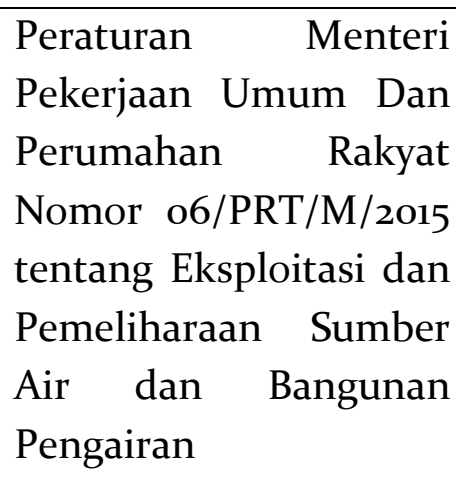 \\
\hline
\end{tabular}

Sumber: JDIHN Badan Pembina Hukum Nasional Kemenkumham RI 2019.

Data tersebut menunjukkan bahwa, tindak lanjut dari Putusan Mahkamah Konstitusi yang tidak memuat tenggang waktu masih bersifat sementara, karena tindak lanjut dari Putusan MK harus berupa Undang-Undang, karena Mahkamah Konstitusi menguji Undang-Undang yang bertentangan dengan Undang-Undang Dasar Tahun 1945, adapun peraturan yang berbentuk Peraturan di bawah Undang-Undang berupa Peraturan Presiden dan Peraturan Menteri bersifat sementara, sampai Undang-Undangnya disahkan.

Tindak lanjut Putusan MK tersebut oleh Pemerintah dan Dewan Perwakilan Rakyat melaui Badan Legislasi (Baleg) dan Menteri Hukum dan HAM (Menkumham) berupa RUU kumulatif akibat putusan Mahkamah Konstitusi sempat dimunculkan dalam Prolegnas prioritas tahun 2013. Namun sampai tahun 2017 RUU tersebut baru sampai tahap perencanaan, padahal berdasarkan ketentuan Pasal 1 ayat (1) Undang-Undang Nomor 12 Tahun 2011 tentang Pembentukan Peraturan Perundang-Undangan menyatakan bahwa Pembentukan Peraturan Perundang-undangan adalah pembuatan Peraturan Perundang-undangan yang mencakup tahapan perencanaan, penyusunan, pembahasan, pengesahan atau penetapan, dan pengundangan. 
Pada tahun 2018, putusan tersebut ditindaklanjuti dalam bentuk RUU, namun tidak mengalami kemajuan yang signifikan, berdasarkan Keputusan Dewan Perwakilan Rakyat Nomor 19 Tahun 2019 tentang Program Legislasi Nasional Rancangan Undang-Undang Prioritas Tahun 2019 dan Perubahan Program Legislasi Nasional Rancangan Undang-Undang Tahun 2015-2019, RUU tersebut sudah sampai tahap pembahasan dan menunggu paripurna penetapan menjadi RUU Inisiatif DPR. Dengan demikian, pada tahun 2013 sampai 2018, Putusan MK yang tidak memuat tenggang waktu, tidak ditindak lanjuti ke dalam undang-undang, namun ditindak lanjuti ke dalam Peraturan Presiden dan Peraturan Menteri.

\section{Tindak Lanjut Putusan Mahkamah Konstitusi yang Memuat Tenggang Waktu dalam Pembentukan Peraturan Perundang-Undangan}

Tabel 2

Tindak Lanjut Putusan MK yang Memuat Tenggang Waktu

\begin{tabular}{|c|c|c|c|}
\hline \multirow[t]{2}{*}{ PUTUSAN } & \multirow[t]{2}{*}{ Model } & \multicolumn{2}{|c|}{ Bentuk Tindak Lanjut } \\
\hline & & Undang-Undang & $\begin{array}{c}\text { Peraturan Presiden } \\
\text { (PP) }\end{array}$ \\
\hline $\begin{array}{l}\text { Putusan MK No. } \\
\text { 32/ PUU-XI/2013 } \\
\text { tentang } \\
\text { Pengujian } \\
\text { Undang-Undang } \\
\text { Nomor 2 Tahun } \\
1992 \text { tentang } \\
\text { Usaha } \\
\text { Perasuransian }\end{array}$ & $\begin{array}{l}\text { Non Self } \\
\text { Executing }\end{array}$ & $\begin{array}{l}\text { Undang-Undang } \\
\text { Tahun } 2014 \quad \text { tentang } \\
\text { Perasuransian. }\end{array}$ & $\begin{array}{l}\text { Peraturan Pemerintah } \\
\text { Nomor } 14 \text { Tahun } 2018 \\
\text { tentang Kepemilikan } \\
\text { Asing Pada Perusahaan } \\
\text { Perasuransian }\end{array}$ \\
\hline $\begin{array}{l}\text { Putusan } \\
\text { Mahkamah } \\
\text { Konstitusi } \\
\text { Nomor 22/PUU- } \\
\text { XV/2017 tentang } \\
\text { pengujian } \\
\text { Undang-Undang } \\
\text { Nomor } 1 \text { Tahun } \\
\text { 1974 tentang }\end{array}$ & $\begin{array}{l}\text { Non Self } \\
\text { Executing }\end{array}$ & - & - \\
\hline
\end{tabular}


Perkawinan.

Sumber: JDIHN Badan Pembina Hukum Nasional Kemenkumham RI 2019.

Data tersebut menunjukkan bahwa, tindak lanjut dari Putusan MK yang memuat tenggang waktu, direspon dengan cepat oleh pembentuk peraturan perundang-undangan. Hal ini terlihat dalam perubahan Undang-Undang Nomor 2 Tahun 1992 tentang Usaha Perasuransian menjadi Undang-Undang Nomor 40 Tahun 2014 tentang Perasuransian.

Selain itu berdasarkan Keputusan Dewan Perwakilan Rakyat Nomor 19 Tahun 2019 tentang Program Legislasi Nasional Rancangan Undang-Undang Prioritas Tahun 2019 dan Perubahan Program Legislasi Nasional Rancangan Undang-Undang Tahun 2015-2019, tindak lanjut putusan Putusan Mahkamah Konstitusi Nomor 22/PUU-XV/2017 tentang pengujian Undang-Undang Nomor 1 Tahun 1974 tentang Perkawinan berupa RUU sudah sampai tahap pembahasan dan menunggu paripurna pengesahan. Dengan demikian ketaatan pembentuk peraturan perundang-undangan terhadap putusan MK yang memuat tenggang waktu sangat tinggi dan bahkan putusan Mahkamah Konstitusi tersebut berwatak implementatif, ketika mencapai tahap aplikasi, Putusan Mahkamah Konstitusi tidak dihadang oleh sekian banyak rintangan yang menggangu eksekusi putusan.

\section{Model Putusan Mahkamah Konstitusi yang Eksekutabilitas Ke Depan}

Bede Harris mengatakan bahwa doktrin konstitusionalisme dalam negara hukum dapat diketahui apakah diimplementasikan atau tidak, dari dihormati dan dilaksanakannya putusan pengadilan. Sehingga dapat ditarik kesimpulan, pengabaian terhadap putusan peradilan, sama halnya dengan pengingkaran dan penghianatan terhadap prinsip negara hukum. Oleh karena itu, diperlukan beberapa langkah alternatif untuk menjadikan Mahkamah Konstitusi sebagai lembaga pengawal konstitusi yang putusannya juga dipatuhi dan ditindaklanjuti: (Dudu Duswara Machmudin, 2018)

\section{1) Tenggang Waktu Pelaksanaan Putusan}

Pasal 47 Undang-Undang Nomor 8 Tahun 2011 jo. Undang-Undang Nomor 14 Tahun 2003 tentang Mahkamah Konstitusi menegaskan bahwa "Putusan Mahkamah Konstitusi memperoleh kekuatan hukum tetap sejak selesai diucapkan dalam sidang pleno yang terbuka untuk umum”. Hal ini menunjukkan bahwa sejak selesainya putusan itu diucapkan atau dibacakan, maka sejak saat itu pula perintah putusan itu harus dilaksanakan. Keadaan ini jelas akan mempersulit addressat putusan untuk menindaklanjuti perintah putusan Mahkamah Konstitusi. Tidak mungkin putusan Mahkamah Konstitusi ditindaklanjuti sesaat seketika setelah putusan itu dibacakan.( Allan Brewer-Carias, 2005)

Dibutuhkan proses dan waktu untuk menindaklanjuti putusan. Hal ini terutama yang berkaitan dengan lembaga legislatif yang 
membutuhkan instrumen hukum baru dalam bentuk revisi atau bahkan undang-undang baru, padahal pembentukan undang-undang berkarakter formal prosedural. Implementasi Undang-Undang tentang Majelis Permusyawaratan Rakyat, Dewan Perwakilan Rakyat, Dewan Perwakilan Daerah, dan Dewan Perwakilan Rakyat Daerah adalah contoh dari dibutuhkannya waktu untuk merevisi dan melaksanakan putusan Mahkamah Konstitusi. Bahkan, upaya untuk melaksanakannya dalam keadaan tertentu tidak dapat dilakukan revisi undang-undang secara langsung, addressat putusan tidak jarang harus mengadakan rapat konsultasi ataupun diskusi bersama Mahkamah Konstitusi untuk mengetahui original intent putusannya. Hal ini menunjukkan bahwa putusan Mahkamah Konsitusi tidak serta merta dapat dilaksanakan seketika saat selesai dibacakan dalam sidang pleno yang terbuka untuk umum itu. (I Dewa Gede Palguna, 2017)

\section{2) Constitutional Question}

Istilah constitutional question adalah suatu mekanisme pengujian konstitusionalitas undang-undang di mana seorang hakim dari Mahkamah Agung atau pembentuk peraturan perundang-undangan yang sedang mengadili atau membentuk suatu perkara menilai atau ragu-ragu akan konstitusionalitas undang-undang yang berlaku untuk suatu perkara, maka ia mengajukan pertanyaan konstitusional ke Mahkamah Konstitusi mengenai konstitusional suatu undang-undang.(I Dewa Gede Palguna, 2010) Constitutional question juga diartika sebagai mekanisme pengujian norma konkret, manakala hakim dari pengadilan biasa sedang memutus sebuah kasus dan dia meyakini bahwa undang-undang yang akan diterapkan dalam kasus tersebut bertentangan dengan konstitusi, maka harus mengajukan pertanyaan kepada Mahkamah Konstitusi.( Alec Stone Sweet, 2007)

Meminjam pendapat I Dewa Gede Palguna menyatakan bahwa mekanisme constitutional question dalam sistem peradilan konstitusi adalah bagian dari pemberian perlindungan maksimum terhadap hakhak konstitusional warga negara. Perlindungan demikian merupakan syarat yang tak dapat ditiadakan dalam setiap negara hukum (yang demokratis).( I Dewa Gede Palguna, 2013) Penormaan mengenai mekanisme constitutional question belum dilembagakan di Mahkamah Konstitusi Republik Indonesia. Akibatnya, ruang pengujian undang-undang masih sangat sempit, yakni hanya menjangkau pengujian norma abstrak dan belum mengatur mengenai pengujian norma konkret atau constitutional question. Padahal berbagai kasus putusan Mahkmah Agung yang menyimpangi putusan Mahkamah Konstitusi diawali dengan persoalan konstitusionalitas dari sebuah peraturan perundang-undangan di proses litigasi dan non litigasi di badan peradilan di bawah Mahkamah Agung.( Arief Ainul Yaqin, 2018) 


\section{Penutup}

Berdasarkan hasil pembahasan tersebut, maka dapat ditarik kesimpulan sebagai berikut, Pertama, putusan Mahkamah Konstitusi tidak berwatak implementatif ketika di dalam putusannya tidak mencantumkan tenggang waktu pelaksanaannya, akibatnya putusan MK menegasikan makna Pasal 24C Ayat (1) UUD Tahun 1945 yang menyatakan bahwa Mahkamah Konstitusi berwenang mengadili pada tingkat pertama dan terakhir yang putusannya bersifat final untuk menguji undang-undang terhadap Undang-Undang Dasar. Sedangkan tindakan berbeda diperlihatkan oleh pembentuk peraturan perundang-undangan menyikapi putusan Mahkamah Konstitusi yang memuat tenggang waktu pelaksanaan putusan oleh pembentuk peraturan perundang-undangan.

\section{References}

Alec Stone Sweet "The Politics of Constitutional Review in France and Europe", International Journal of Constitutional Law, Vol. 5 No. 1, Januari 2007, Faculty of Law Oxford Universty.

Alexander Hamilton, 1995, Federalist 78. In The Federalist Papers, Mentor, New York, hlm. 30.

Allan Brewer-Carias,. "Constitutional Courts As Positive Legislators In Comparative Law", General Report on XVIII International Congress of Comparative Law, Washington, 2010.

Amiruddin, "The Competence of Pretrial Since the Decision of Constitutional Court No. 21-PUU-XII2014", Journal of Legal, Ethical and Regulatory Issues, Volume 21, Issue 2, 2018.

Arief Ainul Yaqin, 2018, Constitutional Question: Kewenangan yang Terlupakan dan Gagasan Untuk Melembagakannya di Mahkamah Konstitusi, Sinar Grafika, Jakarta.

Bayu Dwi Anggono, "The Politics of Law On The Formation of Responsive, Participative and Populist Legislation “, International Journal of Business, Economics and Law, Vol. 9, Issue 4, April 2016.

Dudu Duswara Machmudin, "Modernization and Acceleration of Case Standard Handling and Reviewing on Indonesia Supreme Court", Journal of Legal, Ethical and Regulatory Issues, Volume 21, Issue 3, 2018.

Fajar Laksono Soeroso, "Pembangkangan terhadap Putusan Mahkamah Konstitusi: Kajian Putusan Nomor 153/G/2011/PTUN_JKT” Jurnal Yudisial Komisi Yudisial, Vol.6 No.3 Desember Tahun 2013.

Fajar Laksono, Sudarsono, Arief Hidayat and Muchammad Ali Safaat, "Relation between the Constitutional Court of the Republic of Indonesia and the Legislators according to the 1945 Constitution of the Republic of Indonesia ", Constitutional Review, December 2017, Volume 3, Number 2.

Hermawan Wasito, 1997, Pengantar Metodologi Penelitian Buku Panduan Mahasiswa, PT. Gramedia Pustaka Utama, Jakarta, hlm. 1.

I Dewa Gede Palguna, "Constitutional Complaint and the Protection of Citizens the Constitutional Rights", Constitutional Review, May 2017, Volume 3, Number 1.

I Dewa Gede Palguna, "Constitutional Question: Latar Belakang dan Praktik Di Negara Lain Serta Kemungkinan Penerapannya Di Indonesia”, Jurnal Hukum, Vol. 17 No. 1, 16 Januari 2010, hlm. 119.

I Dewa Gede Palguna, 2013, Pengaduan Konstitusional (Constitutional Complaint): Upaya Hukum terhadap Pelanggaran Hak-Hak Konstitusionalitas Warga Negara, Sinar Grafika, Jakarta.

${ }^{1}$ Keenan D. Kmiec, "The Origin and Current Meanings of 'Judicial Activism”, California Law Review, Volume 92, Issue 5, Oktober 2004

Luthfi Widagdo Eddyono, "Independence Of The Indonesian Constitutional Court In Norms And Practices", Constitutional Review, May 2017, Volume 3, Number 1.

Mahkamah Konstitusi, " Rekapitulasi Perkara Pengujian Undang-Undang”, https:// mkri. id/index.php?page=web.RekapPUU\&menu=5, diakses pada Tanggal 20 September 2019, Pukul 22.00 WIB.

Maria SW. Sumardjono, 2014, Metodologi Penelitian Ilmu Hukum, Gadjah Mada Press, Yogyakarta. 
J.B. Vol.7, Issue 1, Agustus 2019

Muchamad Ali Safaat, Aan Eko Widiarto dan Fajar Laksono Suroso, "Pola Penafsiran Konstitusi dalam Putusan Mahkamah Konstitusi Periode 2003- 2008 dan 2009 - 2013”, Jurnal Konstitusi, Volume 14, Nomor 2, Juni 2017.

Pan Mohamad Faiz, "Dimensions of Judicial Activism In The Constitutional Court Decisions", Jurnal Konstitusi, Volume 13, Nomor 2, Juni 2016.

Soerjono Soekanto, 2018, Penelitian Hukum Normatif Suatu Tinjauan Singkat, Rajawali Press, Jakarta.

Suharsimi Arikunto, 2018, Prosedur Penelitian Suatu Pendekatan, Rineka Cipta, Jakarta.

Syukri Asy'ari, Meyrinda Rahmawaty Hilipito dan Mohammad Mahrus Ali, "Model dan Implementasi Putusan Mahkamah Konstitusi dalam Pengujian Undang-Undang (Studi Putusan Tahun 20032012)", Jurnal Konstitusi, Volume 10, Nomor 4, Desember 2013.

Yustina Trihoni Nalesti Dewi, W. Riawan Tjandra, and Grant R. Niemann, "Independence of Judicial Power as a Foundation of Human Rights Judicial Function in Indonesia," International Journal of Social Science and Humanity, Vol. 6, No. 3, March 2016. 